\title{
Tendenser inom slöjdens forskningsområde
}

\author{
Kajsa Borg
}

\section{Inledning}

Nordisk slöjd- och hantverkstradition är en uråldrig företeelse. Hantverkskunnandet har traderats och utvecklats genom generationers slöjdande från stenåldern och fram till modern tid. Däremot är forskning om och i slöjd och hantverk en mycket ung företeelse som ännu inte har lyckats etablera sig som en självständig akademisk disciplin i samtliga de nordiska länderna. Syftet med denna artikel är att beskriva och analysera skillnader och likheter i hur nationella slöjdforskningsmiljöer utvecklats, från den trevande starten på 1970-talet, till nutid när ett förgrenat forskningsområde växer fram via akademiska institutioner. Det handlar om vilka reella möjligheter till utveckling av ett nytt vetenskapsområde som funnits och vilken riktning utvecklingen tagit. På grund av svårigheterna att med säkerhet definiera relevanta doktorsavhandlingar är det omöjligt att kvantifiera någon form av resultat. I stället får det redovisade antalet avhandlingar vara en indikation på tendenser, dels hur olika ämnesval dominerar i de nordiska länderna dels hur ämnesvalen eventuellt förändrats över tid.

\section{Urval}

De flesta avhandlingar i denna artikel kommer från institutioner som utbildar lärare i slöjd och dess motsvarigheter i Norden. En svårighet i arbetet har varit att bestämma vilka avhandlingar som är relevanta för det pedagogiska slöjdämnet. De obligatoriska skolornas slöjdämne i olika länder har olika innehåll och utformning. Forming/kunst og håndverk ${ }^{1}$ i Norge motsvarar två separata ämnen, bild och slöjd i de övriga nordiska länderna. I Finland finns teknisk slöjd, som har inslag av svensk trä- och metallslöjd och teknikämnet, men skolämnet heter slöjd (fi. käsityö) och innefattar då även den textila slöjden. Ett annat problem är att slöjdämnets hantverksmässiga ämnesinnehåll är multidiciplinärt och överlappar andra forskningsområden. Johansson (2018) har nämnt samma avgränsningsproblem i sin översikt av 100 avhandlingar med slöjdanknytning. Hon beskriver sitt urval som avhandlingar med relevans för slöjdfältet, som kan relateras till slöjd som övergripande paraplybegepp samt avhandlingar där författarna har haft någon anknytning till Nordiskt Forum för Slöjdforskning

\footnotetext{
${ }^{1} 1997$ bytte undervisningsämnet namn från Forming till Kunst og håndverk.
} 
(NordFo). Johanssons studie omfattar ett bredare urval än den studie som beskrivs i denna artikel. En annan studie beskriver liknande urvals- och begränsningsproblem. Kokko et al (2020) har studerat avhandlingar inom craft sciences i Finland, Norge och Sverige, med särskilt fokus på de vetenskapliga metoderna. Tidsmässigt överensstämmer deras undersökningsperiod med materialet $\mathrm{i}$ denna artikel, men Kokko et al. har gjort ett helt annat urval av avhandlingar. I deras undersökning ingår 57 avhandlingar. De inkluderar avhandlingar som i deras text betecknas som käsityötiede (Finland) handlingsbåren kunnskap (Norge) och hantverksvetenskap (Sverige). Det innebär att de avhandlingar som ingår i deras undersökning kan ha stor relevans för slöjdämnet eller också vara helt utan koppling till skolundervisning.

Materialet i denna studie består av 113 avhandlingar som lagts fram vid nordiska universitet och som har anknytning till den pedagogiska slöjden som förekommer i skolor och utbildningsinstitutioner i Norden. Urvalet är tidsmässigt begränsat från när Pirkko Anttila 1983 disputerade vid Helsingfors universitet med den första moderna avhandlingen med slöjdinnehåll och avslutas med fem avhandlingar från våren 2020. Förteckningar över finsk- och samiskspråkliga avhandlingar har inhämtats från professorer vid Åbo universitet, University of Eastern Finland, Helsingfors universitet samt vid Sámi allaskuvla, Kautokeino. Avhandlingarnas titel, abstrakt och var avhandlingen lagts fram har studerats. Avhandlingar med anknytning till kläder och mode har här uteslutits, därför att modevetenskap inklusive dräkthistoria numera är ett eget vetenskapsområde i Sverige,

\section{Akademisering och academic drift}

Den vetenskapliga utvecklingen måste sättas in i en kontext. Akademisering är ett begrepp som betecknar en internationell trend, där allt flera postgymnasiala utbildningar, olika slags ingenjörs-, sjuksköterske- och lärarutbildningar samt många andra yrkesinriktade utbildningar har flyttats in i det akademiska systemet (Kyvik, 2009). Tidigare skedde den större delen av nordiska slöjdlärarutbildningar på seminarier för klasslärare eller i särskilda seminarier för slöjd. Ämneslärare utbildades däremot vid universiteten. I Sverige fattades ett antal politiska beslut från 1970-talet och framåt som eliminerade dessa skolor och seminarier, de ersattes av universitetsinstitutioner. Avsikten med reformerna var att åstadkomma en kvalitetshöjning, att demokratisera utbildningsutbudet samt bidra till en mera allsidig rekrytering av studenter. All högskoleutbildning skall vila på vetenskaplig grund, så i samband med lärarutbildningarnas skifte från seminarie- till universitetsutbildning introducerades ett nytt vetenskapligt ämnesinnehåll (Borg, 2007). Utvecklingen i Norge och Finland följde delvis andra mönster men oavsett organisationsmodell, ökade möjligheterna och kraven för studenter att åstadkomma självständiga akademiska arbeten i samtliga nordiska länder (Kyvik, 2009). 
Diskussionen om den utveckling som skett, görs huvudsakligen med hjälp av begreppen akademisering och academic drift. De två begreppen är delvis överlappande. I denna text används akademisering för de påbjudna organisationsförändringar som är resultat av politisk viljeinriktning och medvetna beslut. Att stänga alla seminarier för lärarutbildningar i slöjd och flytta dem till universitetsinstitutioner samt förlänga utbildningen är ett led i en akademisering. Academic drift är en term som här används för att beskriva de mera otydliga processer som kan vara en slags gradvisa förskjutningar av tyngdpunkter och fokus vilka är svårare att fånga. Det engelska ordet 'drift' betyder att driva för vinden, eller med en ström. Jag har valt att behålla det engelska begreppet, eftersom det bättre täcker den mer eller mindre ofrivilliga förändring som sker när praktikgrundade hantverksutbildningar tvingas in i ett akademiskt mönster. Exempel på academic drift är när praktikgrundad kunskap som tidigare ansetts vara värdefull och användbar i till exempel sjuksköterske- och lärarutbildning gradvis tappade $\mathrm{i}$ betydelse till förmån för textbaserad kunskap. Det resulterade $\mathrm{i}$ att de tidigare täta kontakterna mellan praktik och utbildning försvagades. Utbildningen blir i stället mera integrerad med en eller annan vetenskaplig gruppering (Kyvik, 2009). Vilken vetenskaplig inriktning det blev när det gäller slöjd berodde antagligen mest på personliga kontakter.

För att kunna analysera förändringsprocessen behöver den specificeras, det görs med hjälp av Kyviks begrepp. Policy drift avser de nationella och internationella trender som kan påverka de politiska besluten underifrån. I Sverige ser vi den typen av påverkan när slöjdlärarutbildningarna anpassades till skolornas behov i samband med Grundskollärarreformen (Prop. 1984/85:31). Lärare i slöjd undervisade tidigare endast i slöjdämnet, men de hade behörighet att undervisa elever i alla åldrar. Alla grundskollärare fick i stället behörighet i minst två ämnen för att kunna få större delen av sin tjänst på samma skola. I Sverige fick lärarstudenter med slöjd som ämneskombination följa kursplanen för lärare i årskurs 6-9. Det förutsätts att lärare alltid kan undervisa i lägre årskurser än sitt egentliga kompetensområde. Skolornas huvudmän och lärarnas organisationer hade delvis samma intressen i besluten: att höja lärarnas status, öka deras anställningsbarhet och ge bättre arbetsförhållande.

Programme drift innefattar förskjutningar i ämnesinnehållet. Tidsmässigt har det skett en förskjutning av timfördelningen inom utbildningarna. Den svenska 3-åriga utbildningen förlängdes med ett år, men samtidigt försvann alla krav på förutbildningar inom slöjd och formgivning. De organisatoriska förändringarna resulterade i delvis ändrat kursinnehåll med tillägg av studier och produktion av akademiska texter men en minskning av det slöjdspecifika innehållet. Minimitiden för slöjdämnesstudier var under seminarietiden för textillärarna 1 år av klädsömnad, mönsterkonstruktion, vävning, broderi, tygtryck, fackteckning m.m. Därefter kom en 3-årig seminarieutbildning varav 2 två av åren 
innehöll mera avancerade hantverksstudier. Numera (2020) finns en 4-årig lärarutbildning som innehåller slöjd och andra ämnen, där tiden för ämnesstudier i slöjd varierar, men som vanligtvis omfattar 1 till högst 1,5 år. Denna förändring innebär en minskning av studier i den hantverksmässiga delen inklusive material- och redskapskunskap samt hantverks- och dräkthistoria med 50-65\% (Borg, 2016).

Institutional drift inträffar på institutionsnivå. Här handlar det om tjänstgöringsscheman, arbets- och examinationsformer som förändras och anpassas till, i detta fall, ett akademiskt system. Undervisningsformerna förändrades när lektioner kallades för föreläsningar. Lärarutbildarnas tjänstgöring kom att innehålla minskad närvarotid $i$ ateljéer och verkstäder till fördel för mera tid till handledning och bedömning av studenternas vetenskapliga textproduktion. Studenterna fick färre undervisningstimmar och ökad självstudietid.

Staff drift innebär lärarutbildarnas ändrade fokus för sin egen meritering. De hade tidigare kvalificerat sig inför arbetet som lärarutbildare genom att visa höga betyg från seminarieutbildningen och tjänstgöringsintyg från väl genomförd lärartjänstgöring. Ytterligare meritering fick lärarna genom att gå kurser i speciella hantverkstekniker. Efter akademiseringen fick lärarna en diffus pålaga att meritera sig genom akademiska studier. Den på nationellt plan föreskrivna forskningsanknytningen togs på de svenska institutionerna emot med viss tvekan. I flera fall saknades både förutsättningar och intresse hos lärarutbildarna att börja forska. Seminarieutbildning godtogs inte som grund för akademiska studier, men akademisk meritering var det som krävdes som kompetensutveckling (Erixon Arreman, 2005; Borg, 2007, 2016; Holmberg, 2009).

Student drift avser hur pass stort intresse som studenterna visar gentemot den påbjudna akademiseringen. Studenternas intresse har förändrades från att tidigare visat ett starkt intresse för att studera olika sorters hantverk, deras historia, tekniker, användningsområden och hur de skall läras ut inom ramen för så kallade specialarbeten (Melbye 2013) till att skriva akademiska rapporter där empirin ofta hämtats från texter, enkäter och dokument i stället för mera svårhanterliga klassrumsstudier.

Det är främst inom staff och student drift denna artikels fokus på ämnesval i ett antal doktorsavhandlingar passar in. Hur har ämnesvalen påverkats av studenters och handledares mottaglighet för det som är påbjudet av den akademiska traditionen i kombination med den egna ämnestraditionen?

\section{Avhandlingar}

De första fyra nordiska avhandlingarna med slöjdinnehåll i modern tid, kom på 1980-talet. Pirkko Anttila disputerade 1983 i Helsingfors. I Umeå presenterade historikern Ulla Johansson 1987 en avhandling om de nya ämnen som infördes 
i folkskolan i slutet av 1800-talet. Juhani Peltonen disputerade 1988 och Tapani Kananoja 1989, båda vid Åbo universitet. Under 1990-talet kom 27 avhandlingar och mellan 2001 och 2010 producerades hela 37 avhandlingar. Under tiden 2011 fram till sommaren 2020 har 45 avhandlingar lagts fram.

Tabell 1 visar det antal avhandlingar från respektive land som ingår i denna artikels avgränsningsområde. Siffrorna med + och - tecken anger att en person från Danmark, en person från Sverige samt fyra personer från Norge har genomfört större delen av sin forskarutbildning och disputerat vid Åbo Akademi i Vasa. Tabellen visar en numera stabil nivå på drygt 20-talet avhandlingar per 10 år från fem till sex universitet i Finland. Sverige och Norge har haft en långsammare start i produktionen av doktorsavhandlingar i slöjd och från färre universitet i respektive land.

Tabell 1. Antalet avhandlingar per 10-årsperiod, grundad på forskarnas nationalitet

\begin{tabular}{|l|c|c|c|c|c|}
\hline & $\begin{array}{c}1981 \\
- \\
1990\end{array}$ & $\begin{array}{c}1991 \\
-\end{array}$ & $\begin{array}{c}2001 \\
-\end{array}$ & $\begin{array}{c}2011 \\
-\end{array}$ & Summa \\
\hline Finland & 3 & 15 & 19 & 21 & $58(+6)$ \\
\hline Sverige & 1 & 6 & 9 & 10 & $26(-1)$ \\
\hline Norge & - & 4 & 7 & 11 & $22(-4)$ \\
\hline Danmark & - & 1 & 2 & 2 & $5(-1)$ \\
\hline Island & - & 1 & - & 1 & 2 \\
\hline SUMMA & $\mathbf{4}$ & $\mathbf{2 7}$ & $\mathbf{3 7}$ & $\mathbf{4 5}$ & $\mathbf{1 1 3}$ \\
\hline
\end{tabular}

Eftersom Danmark och Island redovisar ett alltför begränsat antal avhandlingar för att några tendenser ska kunna iakttas, ges här endast en kommentar. Danmarks lärarutbildningar i sløjd och håndarbejde har under den aktuella tidsperioden genomgått ett antal omorganisationer. De båda slöjdämnena slogs samman till ett nytt ämne materiell design från och med 2007. Lärarutbildningens organisation och svårigheter att erhålla forskningsmedel har antagligen bidragit till att endast fem personer hittills har valt att bli slöjdforskare, varav en person disputerat i Vasa, Finland. Islands två disputerade slöjdforskare har disputerat i Canada och i England. Den ena med textillärares levnadsberättelser i fokus, den andra handlar om virtual reality inom Innovation Education, vilket är ett betydande inslag i isländsk slöjdundervisning. Ämnesområdet Design og håndverk har en svag vetenskaplig bas. Det finns endast ett fåtal forskningsrapporter (Gulliksen \& Johansson, 2008).

Finlands, Norges, och Sveriges avhandlingar med slöjdanknytning analyseras närmare i följande text.

\section{Finland}


Lärarutbildningarna i Finland överfördes till universiteten1974-75. I samband med detta inrättades biträdande professorstjänster i respektive slöjdarts didaktik vid de finskspråkiga lärarutbildningarna i Helsingfors universitet och Åbo universitet i Raumo. Pedagogiska fakulteten vid Helsingfors universitet var först med att etablera textillära, sedermera slöjdvetenskap, som forskningsämne 1982. Studenter kunde avlägga kandidatexamen med textilslöjd som huvudämne och pedagogik som biämne (ur föreläsning av P. Anttila i Notodden 1988). I Raumo inrättades 1986 en professur i pedagogik, företrädesvis slöjdfostran (käsityökasvatus) vilken innehades av Juhani Peltonen. 1990 tillkom en biträdande professorstjänst $i$ textilslöjd (tekstiilityö) vid Joensuu universitet $i$ Nyslott och till sist fick den svenskspråkiga lärarutbildningen vid Åbo Akademi i Vasa 1991 en biträdande professorstjänst i pedagogik, företrädesvis slöjdpedagogik (Lindfors, 1992). Pirkko Anttila blev Nordens första professor med slöjd som ansvarsområde. Anttila började formulera de filosofiska och ontologiska grunderna för slöjdvetenskap. Inspirerad av Yrjö Engeström konstruerade Anttila sin egen triangel, där spetsarna representerade människan, omgivningen och teknologin (Antitla i Mellbye 2013). Vid pedagogiska fakulteten, Åbo Akademi i Vasa arbetade Linnéa Lindfors med sin grundforskning att formulera det slöjdpedagogiska paradigmet (Lindfors, 1992).

Från 1975-1991 inrättades fyra biträdande professorstjänster och två professurer med inriktning mot slöjd (Lindfors, 1992). Senare har flera professorstjänster tillkommit. Nya lärosäten med forskningskompetens tillkom, 1997 presenterades den första avhandlingen vid Jyväskylä universitet, därefter har disputationer med slöjdforskningsinnehåll även lagts fram vid universiteten i Joenusu ${ }^{2}$ och Uleåborg Finlands satsning på att tidigt tillsätta professorer i slöjd har gett resultat. Den vetenskapliga produktionen av texter kom igång och Finland är nu det land i Norden som har flest antal disputerade inom slöjdområdet, 64 avhandlingar har lagts fram från 1983 till 2020.

De finska professorerna hade större ambitioner, de var villiga att också arbeta med nordiska studenter och doktorander. LinnéaLindfors tillsammans med Juhani Peltonen initierade ett nordiskt forskningsprojekt Slöjdkompetens $i$ nordisk kultur 1995-1998, med deltagare från Sverige, Norge, Finland, Danmark och Sapmi. Värdet av dessa professorers arbete för att utbilda en grupp nordiska lärarutbildare och studenter, som då var i början av sin forskarutbildning, kan knappast överskattas ${ }^{3}$. Regelbundna träffar några gånger per år på olika platser samt textproduktion med handledning och seminarieövningar blev en god introduktion i forskarvärlden. Projektet resulterade blnd annat i ett nummer med artiklar med slöjdtema av tidskriften Nordisk Pedagogik 1999.

\footnotetext{
${ }^{2}$ Universiteten i Joensuu och Kuopio slogs samman 2010 till University of Eastern Finland.

${ }^{3}$ Medlemmar i gruppen var bland andra K. Borg, M. Dunfjell, G. Guttorm, M. Johansson,

S. Kjosavik, M. Porko, C. Nygren-Landgärds, E. Malmberg och P. Kankare
} 
Tabell 1 visar tydligt vad den finska satsningen betydde för att så fort som möjligt åstadkomma en vetenskaplig grund för slöjdämnena. Den visar också att satsningen fortsätter att ge utdelning i form av flera nya doktorer varje år.

\section{Norge}

I Norge utvecklades en alternativ väg som brygga mellan grundutbildning och forskning, genom att man 1976 i Notodden och i Oslo började arbeta med hovedfag, ändrat till mastergrad 2002. (Gulliksen \& Johansson, 2008). Studierna baserades på en 2-årig akademisk grundutbildning. Hovedfag innebar en kombination av, i detta fall, forming, med ett begynnande vetenskapligt tänkande. Studierna blev tvärfackliga med mål att utveckla studenternas kreativa förmåga genom praktisk estetisk verksamhet samtidigt som studenterna också skulle tillägna sig pedagogisk didaktiska, vetenskapliga och metodiska kunskaper. I utbildningen ingick att avgränsa ett ämne, att planlägga och genomföra ett projekt med en tillräckligt väl utförd dokumentation av det praktisk estetiska arbetet samt en skriftlig/illustrativ rapport där ämnesteori och ämnesdidaktik belyser varandra. Stor vikt lades vid utforskande arbete både $i$ och $o m$ den praktiska estetiska verksamheten i materialen. Kunskaper både från det egna ämnesområdet och från akademiska discipliner som konsthistoria, pedagogik, psykologi och filosofi och senare även från arkitektur har använts. Studierna behövde inte ha något närmare samband med skolämnet forming (Melbye, 2013). Genom denna studiemöjlighet har norska forskare utvecklat vana att hantera estetiska och kulturella frågor och värden i både gestaltningar och i text.

Else-Marie Halvorsen disputerade 1996 vid den Utbildningsvetenskapliga fakulteten, Oslo universitet med en avhandling som behandlade hur det estetiska kulturarvet överförs mellan generationer. Inte förrän Arkitektur- og Designhøgskolen i Oslo och universitet i Bergen 1995 öppnade doktorsprogram för andra professioner än arkitekter, skapades det en möjlighet för formingslärare, konstnärer och designers att disputera inom sitt eget kunskapsfält. Jorun Spord Borgen blev den första formingsläraren som antogs som doktorand efter att hon tagit en magisterexamen i Konst och design. Hon disputerade i konstvetenskap 1998 vid Bergens universitet. Liv Merete Nielsen, blev den första att disputera vid Arkitektur- og Designhøgskolen i Oslo, 2000 (Nielsen i Lindström 2008). De allra flesta norska avhandlingarna har presenterats vid Arkitektur- och designhøgskolen i Oslo (8), Universitetet i Oslo (3), Tromsö (3) samt vid Åbo Akademi i Vasa, Finland (4). Enstaka avhandlingar har lagts fram vid universiteten i Bergen, Trondheim och Oslo Metropolitan University.

När vetenskapligt skolade ämnesföreträdare/professorer med slöjd/formingskompetens saknades vid en institution tillgodosågs kompetensen genom inlånade eller tillfälligt anställda professorer. Det dröjde till 2002 innan Else- 
Marie Halvorsen blev professor i Fagdidaktikk/Formgivning og Kunst og håndverk vid Høgskolen i Telemark ${ }^{4}$. Liv-Merete Nielsen blev 2003 professor i Forming - skapande arbeid också vid Høgskolen i Telemark och senare samma år professor i Designdidaktikk vid Høgskolen i Oslo, numera Oslo Metropolitan university. Både Halvorsens och Nielsens arbete har haft betydelse för efterföljande forskarstuderande.

Vid Arkitektur- og Designhøgskolen i Oslo startades ett nytt vetenskapsområde The making disciplines, som erbjöd högre studier inom ett multidisciplinärt fält, där även slöjd kunde passa in. Med denna bredare ämneskonstruktion ville man snabbare kunna åstadkomma en tillräckligt stor kritisk massa inom ämnesområdet (Nielsen, 2008).

\section{Sverige}

I samband med att slöjdlärarutbildningarna flyttades från seminarier till universitetsinstitutioner i slutet av 1970-talet krävdes att studenterna skulle skriva ett specialarbete inom ramen för sin lärarutbildning i slöjd. Det blev en stor utmaning. Slöjdämnet var väl förankrat i ämnestraditioner och undervisningspraxis men saknade varje form av vetenskapstradition. Då de flesta lärarutbildare i slöjd saknade anknytning till akademiska ämnesstudier, blev studier i pedagogik det vanligaste ämnesområdet för vidare studier (Erixon Arreman, 2005). Två undantag fanns vid textillärarutbildningen i Uppsala: Gunhild Engholm, som redan 1954 skrivit en licentiatavhandling i konsthistoria ${ }^{5}$ samt Merin Trapp, som skrev den första moderna beskrivningen av svensk skolslöjds historia, med tillhörande analys i en C-uppsats vid Institutionen för pedagogik, Uppsala universitet 1973. Lärarutbildarna i slöjd samarbetade även med pedagogiska institutioner, till exempel projektet Skolan och slöjden som genomfördes under åren 1976-1980 i samarbete med den Pedagogiska institutionen, Linköpings universitet.

Det var inte bara slöjdämnet som drabbades av problem med att genomföra ämnesforskning på grund av kompetensbrist, detta gällde generellt för de lärarutbildningar som saknade vetenskaplig hemvist (Erixon Arreman, 2005). I slutet av 1990-talet påtalades behovet av att bredda, fördjupa och förstärka forskning och forskarutbildning i anslutning till lärarutbildning och pedagogisk yrkesverksamhet (SOU 1999:63). Ett nytt tvärvetenskapligt och yrkesinriktat forskarutbildningsämne Pedagogiskt arbete inrättades vid universiteten, bland annat i Linköping, Göteborg och Umeå. Den första forskarskolan startade 2001 (Erixon Arreman, 2005). Det nya ämnet skiljer sig från ämnet pedagogik genom att

\footnotetext{
${ }^{4}$ Høgskolen i Telemark och i Rauland ingår numera som enheter i Universitetet i sørøst Norge.

${ }^{5}$ Se v Gegerfelt Kronberg i denna publikation.
} 
behandla mera praktiknära frågor. Det nya ämnet gav möjligheter för slöjdlärare och slöjdlärarutbildare att disputera med fokus på frågor som berör slöjdämnet och aktiviteter i slöjdsalarna. Hitintills (2020) har fyra avhandlingar ${ }^{6}$ med slöjdfokus lagts fram i ämnet Pedagogiskt arbete vid Umeå universitet.

Två slöjdintresserade professorer, i pedagogik och i estetiska ämnenas didaktik, har varit särskilt betydelsefulla för svensk slöjdforskning. De har utbildat, handlett och examinerat många slöjdforskare. Sven Hartman ledde på 1990-talet ett slöjdhistoriskt forskningsprojekt, vilket bidragit med kunskap om och intresse för slöjdämnets historiska utveckling. Han har även medverkat i ett stort antal konferenser och publikationer, där han bland annat lyfter fram hantverkskunskapernas betydelse som bildning och kultur. Den andre var Lars Lindström, som intresserade sig för estetiska skapandeprocesser och bedömningsfrågor i estetiska ämnen. Han var vetenskaplig ledare för ett 4-årigt forskningsprojekt Kommunikation och lärande i slöjdpraktiker, finansierat av Vetenskapsrådet, vilket förutom 2 doktorer genererat ett stort antal vetenskapliga texter (Gulliksen \& Johansson, 2008; Borg, 2009).

I Sverige har 23 av 26 avhandlingar (se tabell 1) med slöjdforskningsinnehåll lagts fram på orter där det funnits lärarutbildning i slöjd. En person från Sverige har disputerat vid Åbo Akademi, Vasa. Enstaka avhandlingar har också lagts fram vid Luleå tekniska universitet och Lunds universitet. Till skillnad från Finland finns det fortfarande inte något vetenskapligt definierat slöjdforskningsområde. Inte heller har alla handledare för doktoranderna haft slöjdkompetens. Svenska avhandlingar är därför skrivna inom många olika forskarutbildningsämnen som pedagogik, etnologi, hushållsvetenskap, pedagogiskt arbete samt textilvetenskap (Johansson, 2018). Sverige fick sin första och hittills enda ämneskompetenta professor i slöjd först 2013 då Marléne Johansson blev professor vid Göteborgs universitet, dock utan att ha ett eget definierat vetenskapligt område. Det står klart att slöjdforskningen i Sverige har utvecklats med hjälp av eldsjälar, trots det nästan obefintliga stödet på nationell eller lokal nivå.

\section{Tendenser $\mathrm{i}$ avhandlingarnas ämnesval}

Det existerar parallellt en mångfald av kategoriseringar vilket bidrar till svårigheterna att avgränsa vetenskapsområdet. Arne Marius Samuelsson urskiljer tre kluster inom ämnesvalen i Norge: läroplansstudier eller form, färg och komposition samt material, verktyg och teknik (Samuelsson i Lindström 1998). I översikten från 2008 (Gulliksen \& Johansson red.) beskrivs det finska forskningsfältet i tre kategorier: slöjdpedagogik med slöjdämnet som inriktning,

\footnotetext{
${ }^{6}$ Mäkelä 2011, Sigurdson, 2014, Westerlund, 2015 och Jeansson, 2017.
} 
slöjdpedagogik med slöjd som helhetsverksamhet och slöjdvetenskap. När det gäller de 100 nordiska avhandlingar som ingår i Johanssons genomgång, används en indelning i fem temata: pedagogiskt/didaktisk, lärar-/hantverksutbildning, historisk, estetisk/kulturell och teknisk/naturvetenskaplig (Johansson, 2018). I Kokko et al. (2020) ingår delvis samma avhandlingar, som där kategoriseras som craft-interpretations, -amplification, -reconstruction, -elicitation, socialization. Eftersom denna artikel söker beskriva tendenser i ämnesval samt skillnader över tid, väljer jag här att mera skissartat beskriva de vanligaste ämnesvalen.

Det finns många likheter mellan de nordiska länderna. I alla tre länderna är omkring hälften av respektive lands avhandlingar pedagogiskt/didaktiska (Johansson, 2018). Detta kan förklaras av att de allra flesta forskarna har varit knutna till institutioner med lärarutbildning, liksom deras handledare. Inom lärarutbildningarna finns ofta ett etablerat samarbete mellan ämnesinstitutioner och pedagogiska institutioner, eller som i Finland där slöjdutbildningarna och forskningen hör till de pedagogiska vetenskaperna och fakulteterna vid samtliga universitet. I alla tre länderna finns avhandlingar som behandlar skolämnets historiska utveckling, läroplansstudier samt lärarutbildningens innehåll och organisation. Från Finland, Norge och Sverige kommer också avhandlingar som fokuserar slöjdämnets och dess motsvarigheters innehåll och metoder. Genusfrågor har likaså behandlats i någon/några avhandlingar från varje land. I alla de tre länderna är det ett fåtal avhandlingar som har huvudfokus på utövande och utveckling av hantverk.

Exempel på det som skiljer länderna emellan är att det grundläggande forskningsarbete de första finska professorerna gjorde med begrepps-, system- och paradigmutveckling, saknar sina motsvarigheter i Sverige och Norge. I Sverige saknas avhandlingar som behandlar slöjdaktiviteter i förskola och grundskolans lägre klasser, medan de yngre barnens slöjdande har intresserat några slöjdforskare i både Norge och Finland. I Sverige har det skrivits ett antal texter om slöjdhistoria, särskilt kring tiden 1880-1920, som kan kallas slöjdens guldålder eftersom ämnet introducerades och blev allmänt populärt i folkskolorna under denna tid. I Finland och Norge har endast enstaka avhandlingar haft huvudfokus på den äldre ämneshistorien. I Norge dominerar de estetiskt/kulturella ämnesvalen i doktorsavhandlingarna. Den samiska slöjden (duodji) finns representerad med två avhandlingar från Tromsö universitet i Norge ${ }^{7}$ samt en avhandling från Uleåborg universitet i Finland ${ }^{8}$. Från både Norge och Finland kommer även andra avhandlingar som berör etnicitet och kulturella minoriteter, men motsvarande ämnesval saknas från Sverige. I Finland har många disputerat med avhandlingar som berör den

\footnotetext{
${ }^{7}$ Dunfjeld 2002, Guttorm 2003

${ }^{8}$ Magga, 2018
} 
tekniska slöjden, ett ämne som inte har någon exakt motsvarighet varken $\mathrm{i}$ Sverige eller Norge. Virtuellt slöjdande och IT-frågor har undersökts av några finländska doktorander.

\section{Tendenser över tid}

För att kunna diskutera eventuella förskjutningar i ämnesvalet från 1980-talet till 2020, inom den snäva tidsramen för denna studie, har de fem tidigaste och de fem senaste avhandlingarna i varje land valts ut, se Tabell 2 . I de tidigaste 15 avhandlingarna är avhandlingsämnena ganska jämt fördelade mellan grundforskning, kulturfrågor, pedagogik/didaktik och ämneshistoria. I denna grupp ingår den tidigare nämnda finska grundforskningen (Anttila, 1983, Peltonen, 1988, Lindfors, 1992) även Sjögrens avhandling (1997) innehåller betydelsefulla avsnitt där kunskapsbegreppet grundligt utreds. Fyra avhandlingar berör kulturarv och kulturöverföring (Halvorsen 1996), kulturtraditioner och kulturell kompetens (Borgen, 1997) kläder som kultur och handling (Jacobsson, 1994) samt samisk kultur (Dunfjeld, 2002). Kananoja (1989), Kolehmainen (1989), Berge (1992) och Nielsen (2000) kan, trots mycket olika forskningsfokus, bilda en pedagogisk/didaktisk kategori. Till sist finns de som skrivit om ämneshistoria i olika skolformer (Hartman P. 1993, Johansson, 1987 och Kjosavik 1998).

För den som vill studera de mellanliggande åren hänvisas till två mindre översikter av forskningsläget, Kärnä-Behm och Salo-Mattila (2002) samt Gulliksen \& Johansson (2008).

Tabell 2. Ämnesfördelning över tid och länder. Urval: de första fem och de sista fem avhandlingarna i varje land.

\begin{tabular}{|c|c|c|c|c|c|c|c|c|c|c|c|}
\hline & \multicolumn{3}{|c|}{$1981-1990$} & \multicolumn{3}{|c|}{ 1991- 2000} & \multirow{2}{*}{$\begin{array}{c}2001 \\
- \\
2014 \\
\end{array}$} & \multicolumn{3}{|c|}{$2015-2020$} & \multirow{2}{*}{$\begin{array}{c}\text { SUM } \\
\text { MA }\end{array}$} \\
\hline & & NO & & $\mathbf{F}$ & NO & SV & & FI & NO & SV & \\
\hline grundforskning & 2 & & & 1 & & 1 & & & & & 4 \\
\hline $\begin{array}{l}\text { kultur/estetiska } \\
\text { frågor }\end{array}$ & & & & & 3 & 1 & & & 1 & 1 & 6 \\
\hline $\begin{array}{l}\text { pedagogik/ } \\
\text { didaktik }\end{array}$ & 2 & & & & 1 & 1 & & 3 & 2 & 2 & 11 \\
\hline ämneshistoria & & & 1 & & 1 & 1 & & & & & 3 \\
\hline IT/datorer & & & & & & & & 1 & & & 1 \\
\hline $\begin{array}{l}\text { hållbart } \\
\text { samhälle }\end{array}$ & & & & & & & & 1 & 2 & 1 & 4 \\
\hline hantverk & & & & & & & & & & 1 & 1 \\
\hline SUMMA & & 5 & & & 10 & & - & & 15 & & 30 \\
\hline
\end{tabular}

De allra färskaste 15 avhandlingarna kommer från åren 2015-2020. Hälften av dem har kategoriserats som pedagogiska/didaktiska, (Westerlund, 2015; Randers-Pehrson, 2016; Härkki, 2018; Jeansson, 2018; Yliverronen 2019, 
Maapalo, 2019 samt Viilo, 2020) samt två som mera specifikt behandlar lärprocessers estetiska dimensioner (Hansson Stenhammar, 2015) och utställningars retorik (Tronshart, 2016). Här återfinns också två nya ämnesområden dels hållbart/cirkulärt samhälle (Hofverberg, 2019; Väänänen, 2020; Glitsch, 2020 och Maus, 2020) dels IT i undervisningen (Vilhunen, 2018). Till sist finns också en enda avhandling som till hälften ägnas åt djupgående studier av två ej så vanliga textila broderitekniker i Sverige: pinnspets och näversöm (Ericsson, 2018).

Att döma av jämförelsen mellan de tidigaste och de senaste avhandlingarna i Finland, Norge och Sverige visar det sig att de nyare doktorerna inte längre ägnar utrymme åt att utreda ämnets bakgrund, dess historia och styrdokument. Endast Jeansson (2018) har studerat lärares uppfattningar av den senaste kursplanen i slöjd i Sverige och relaterat till tidigare kursplaner. Många forskare har riktat sitt intresse mot estetiska lärprocesser både implicit och explicit, vilket möjligen kan vara ett tecken på att författarna uppfattar detta moment $\mathrm{i}$ undervisningen som något som är oklart, kanske svårfångat och därför bör beforskas. Att fyra nya avhandlingar behandlar slöjdens möjligheter att bidra till ett hållbart samhälle, visar att författarna är lyhörda för de samhällsbehov som nu är aktuella. Samtidigt som att laga det som är trasigt, ta tillvara och utnyttja material på ett ändamålsenligt sätt är ett ämnesinnehåll som inte är nytt. Det har funnits med i ämnet sedan allra första början i slutet av 1800-talet.

\section{Sammanfattande kommentar}

Utvecklingen inom slöjdområdet ingår $\mathrm{i}$ en internationell trend av akademisering som går ut på att föra in postgymnasiala och semiprofessionella utbildningar i det akademiska systemet. Förändringarna byggde på en allmän tilltro till att den vetenskapliga grunden utgör en kvalitetsgaranti för ALL utbildning - även om vissa utbildningar från början saknade vetenskaplig grund. Handlingsburna kunskaper och erfarenheter nedvärderades redan i antagningskraven till utbildningarna och ersattes av krav på genomgången gymnasieutbildning. Textbaserade studier fick större utrymme inom programmen. Slöjdlärarutbildare och studenter började producera egna texter med en med åren ökande vetenskaplig nivå. Doktorsavhandlingar i större mängd började produceras på 1990-talet.

Att akademisera slöjdlärarutbildningar har tagits om hand på olika sätt i de nordiska länderna, vilket tydligt framgår i denna studie, men det finns också generella likheter. Forskare har arbetat var för sig men också tillsammans, bland annat inom nätverket NordFo med att utveckla slöjdämnets vetenskapliga grund. Det tar tid innan en kritisk massa uppnås i varje land. Det nordiska samarbetet har här varit mycket värdefullt, då det breddat fältet och skapat många tillfällen till erfarenhetsutbyte. 
En tydlig tendens är att hantverkskunnandet försvinner ur fokus för forskningen. Från allra första början formulerades forskningsinriktningen nära den hantverkliga utbildningen. Ämnen för svenska studenters specialarbeten på 1980talet var tätt knutna till det hantverksmässiga ämnesinnehållet. Ofta studerades en hantverksteknik, dess historia och användningsområden. Pirkko Anttilas professur i textillära preciserades först som "planeringen och förverkligandet av handgjorda textila produkter" (Anttila i Melbye 2013, s.172). Av de tidiga hovedfagsoppgaverna i forming 1976-1999 i Norge var 50\% studier av material och hantverk samt studier med bas i artefakter och deras kontext (Melbye, 2013). Forskningsintresset har förskjutits från hantverket till didaktiska och pedagogiska frågeställningar. Att döma av titlar och abstrakt i denna studie är det endast ett fåtal avhandlingar i respektive land som i någon form behandlar studier i eller om hantverkstekniker med eller utan direkt koppling till skolundervisning. Liknande ämnesval återfinns i all tre länderna. På senare tid har avhandlingarna behandlat betyg och bedömningsfrågor, ämnesdidaktik, ITfrågor, genusproblematik, designprocesser och kulturprojekt i skolan. Från 2019 och 2020 har en avhandling från Sverige, en från Norge och två från Finland inriktats på frågor om slöjdens bidrag till ett hållbart samhälle.

Den tydligaste tendensen är att pedagogik/didaktik har fått en odiskutabel dominans, ca $40 \%$ av avhandlingarnas innehåll. Det som kan kallas för beprövad erfarenhet inom slöjdläraryrket har hamnat i en underordnad position jämfört med etablerade akademiska ämnen. Handlingsbaserad slöjdkompetens kan endast uppnås genom att arbeta med verktyg i material. I sådant arbete har även tidsfaktorn betydelse. De organisatoriska och ekonomiska ramarna innanför universiteten begränsade troligen möjligheterna att göra slöjdmässiga prioriteringar, och som en konsekvens har studenter, lärare och administratörer drivit med i den akademiska strömmen mot pedagogik och andra vetenskapsområden där det funnits kompetenta handledare.

Sambandet mellan slöjdforskare och forskningsämnet pedagogik samt deras handledare som ofta själva disputerat i beteendevetenskapliga ämnen, kan ha bidragit till att de rent hantverksmässiga forskningsfrågorna som material- och teknikexperiment, verktygs- och formgivningsutveckling inte har valts som forskningsobjekt. Inom slöjdämnesfältet passar inte alltid vedertagna teorier och metoder i pedagogik. Vad styrde doktoranders val av forskningsämne? Hur påverkas det inomvetenskapliga kunskapsbygget när kritik och granskning kom från andra ämnesområden? Almevik (2019) har skrivit om utvärderingar av lärandemål i svensk hantverksinriktad högskoleutbildning, vars innehåll till viss del motsvarar de hantverksmässiga delarna i slöjdlärarutbildningarna. Han konstaterar att utvärderingarna systematiskt bortser från att beröra utbildningens professionsinriktning. Vid utvärderingar av lärarutbildningar riktas intresset vanligtvis mot kvaliteten i studenternas självständiga skriftliga arbeten, inte mot 
vilken kunskapsnivå som studenterna uppnått i formgivning, teknik- och materialhantering. Det saknas incitament för att på akademisk nivå utveckla slöjdämneskunskaperna. Utvärderingsformen leder till en likriktning av utbildningar, medan vetenskaplig slöjdkunskap kräver utveckling av ämnets särart. Den djupa ämneskunskap som före akademiseringen var kännetecknade för lärarutbildarnas speciella yrkeskunnande har delvis ersatts av disputerade lärarutbildare med kompetens att själva skriva och handleda andra i skrivande av akademiska texter.

En annan tendens synlig i materialet är problemet med att definiera och bestämma slöjdforskningsområdet. Listan på den stora mängden akademiska institutioner där slöjdavhandlingar lagts fram (se bil.) vittnar om både problem och möjligheter, dels brist på tydlig hemhörighet, dels många möjliga anknytningsytor. Från början bildade slöjdlärarseminarierna egna universitetsinstitutioner för slöjd, men med tiden har universitetsorganisationen ombildats och mindre institutioner har slagits samman till större enheter i Sverige. I Finland och Norge har mindre högskolor och universitet slagits samman till större enheter. Slöjdföreträdare, hamnar numera oftare i minoritetsställning inom de större organisationerna. De har behövt omformulera och vidga det vetenskapsområde där slöjd kan ingå i diskussion med andra. Att tänka större än slöjdämnet kan vara både inspirerande och nödvändigt, men det kan också innebära att en vetenskaplig slöjdmiljö, som fungerar som en kritisk massa, inte finns på hemmaplan utan måste sökas i vidare kretsar, som till exempel i det nordiska samarbetet.

Själva namnet slöjd har också ifrågasatts. Designbegreppet i en vid bemärkelse har använts som ett samlande begrepp för konst, konsthantverk, design, och arkitektur samt av slöjdforskare. Forskarnätverket DesignDialog arbetade för att designers och användare ska kunna mötas i en demokratisk dialog och hade sin hemvist på Avdelningen for Estetiske fag vid Oslo Metropolitan University (Nielsen, 2004). Nya ämnesgrupperingar har konstruerats, när psykologi, pedagogik och konstvetenskap inte räckte som vetenskaplig bas. Till exempel The making diciplines i Norge där studier av undervisningspraktik och studieresultat varit dominerande liksom teoretiska och epistemologiska analyser av artefakter i relation till undervisningsprocesser (Nielsen, 2008). Vid Åbo Akademi i Vasa ändrades namnet på huvudämnet från slöjdpedagogik till slöjdvetenskap (eng. craft science) studieåret 2015-2016. Ämnet är även i fortsättningen placerat inom det pedagogiska ämnesfältet. Motiveringen till förändringen var att slöjd numera inte enbart ska kunna förknippas med skolslöjd utan kan även kopplas till andra ämnesområden som etnologi, ekonomi, masskommunikation etc. Det finns då möjligheter att på avancerad nivå studera slöjdmaterial, tekniker och skapandeprocesser i relation till flera andra vetenskapsområden (pers. kom. Porko-Hudd, 2020). Kokko et al. (2020) påtalar 
positioneringsproblem när man använder Craft science som likvärdigt med hantverkskunskap, eftersom science associerar till naturvetenskap i engelskspråkiga länder och därmed saknar koppling till konst, bild, form och estetiska uttryckssätt. De föreslår att man i stället använder craft sciences för att visa på den innehållsliga bredden. I en studie av de vetenskapliga metoder som används inom käsityötiede (Finland), handlingsbåren kunnskap (Norge) och hantverksvetenskap (Sverige) påstås att de pedagogiskt inriktade studierna valts bort och ingår ej i studien (Kokko et al.2020). Ändå ingår vissa avhandlingar i både denna studie och i Kokkos rapport.

De organisatoriska förändringar som initierades i samband med den svenska högskolereformen 1977 (SFS 1977:283) och som sedan gradvis förändrat seminarieutbildningarna till en traditionell akademisk utbildning, var avsedda att höja utbildningens generella kvalitet. Den akademiska nivån har otvivelaktigt höjts, forskningen har bidragit med tidigare okända perspektiv på slöjdämnets utveckling, slöjdundervisningens genomförande, på lärarnas förhållningssätt, slöjdämnenas kulturella bidrag och möjligheter att bidra till ett hållbart samhälle. Datorn som hjälpmedel och problematisering av slöjdämnets hantering av genusfrågor har också behandlats i avhandlingar, men bara ett fåtal avhandlingar har skrivits om utveckling av slöjdämnets kärnverksamhet, arbetet med redskap och verktyg i olika material.

Kyvik (2009) diskuterar om akademiseringsprocessen kan ses som hierarkisk, det vill säga startar i politiska beslut, för att sedan passera nedåt genom nivåerna, eller om det handlar om en interaktion mellan olika nivåer. Han konstaterar att drift på en nivå kan orsaka drift även på andra nivåer. Olika agenter kan påverka oberoende av varandra, och det sammantagna resultatet kan vara svårt att förutse från respektive nivå. En ökande teknisk och vetenskaplig utveckling kan också leda till nya krav på innehållet i olika utbildningar. En annan aspekt som påverkar tyngdpunktsförskjutningar är att huvudmännen strävar efter att minska sina kostnader för exempelvis specialutrustade lokaler, inköp och underhåll av maskiner och verktyg, materialkostnader (Kyvik, 2009). Det framgår av denna studie att alla förändringar på olika nivåer som Kyvik definierat som policy drift, programme drift, institutional drift, staff drift och student drift har påverkat slöjdområdets vetenskapliga utveckling. Det kan också konstateras att ämnesvalen riktats mera mot studier om slöjd i olika sammanhang, i stället för studier i slöjdande praktik.

Vissa tendenser i befintlig slöjforskning har iakttagits i ovanstående text. Var denna utveckling förutsedd och förväntad, eller har den akademiska strömmens olika nivåer var för sig medverkat till att det hantverkliga innehållet minimerats i forskningen? Nu står vi inför en okänd framtida utveckling av ett akademiskt ämnesfält. Eftersom slöjdforskning i Finland, Norge och Sverige har utvecklats med grund i olika traditioner och på olika villkor, kan man förutse att det även $\mathrm{i}$ 
fortsättningen kommer att finnas både likheter och olikheter mellan länderna. En tänkbar tendens i framtida slöjdforskning skulle kunna vara en tydligare uppdelning mellan den pedagogiskt/didaktiska forskningsinriktningen knuten till lärarutbildningens institutioner och en mera konstnärligt inriktad forskning med hemhörighet vid helt andra institutioner. Utifrån svensk tradition skulle en sådan utveckling riskera att ytterligare utarma den material/teknik/formgivningsforskning som skulle kunna bidra till att utveckla slöjdämnets uttrycksformer. Kommer färg, form, funktion, materialhantering och hantverkstekniker att kunna balanseras mot befintliga förutsättningar och gällande styrdokument?

Är slöjdämnet och dess nordiska motsvarigheter på väg att ändra inriktning?

Vem eller vad kan styra strömmen?

\section{Referenslitteratur}

Almevik, G. Hantverksvetenskap och vetenskapligt hantverk. Om utvärdering och lärandemål i hantverksinriktad högskoleutbildning. FormAkademisk Vol.12/nr 1/2019. https://doi.org/10.7577/formakademisk.2310

Anttila, P. Slöjd som vetenskap. I: Melbye, E. (red.) I: Jubileum og visjoner. Institutt for forming og formgivning -75 år på Notodden. Techneserien - Forskning $i$ slöjdpedagogik och slöjdvetenskap B:17/2013.

Borg, K. Slöjdforskning i Norden. I Tilde, Tema slöjd. Rapport $n r$. 16, 2016. Institutionen för estetiska ämnen, Umeå universitet.

Borg, K. Communication and Learning in Sloyd Practises - A Research Project. I: Techneserien - Research in Sloyd Education and Crafts Science A:14/2009

Borg, K. Akademisering: En väg till ökad professionalism i läraryrket? I Pedagogisk Forskning i Sverige. Årg. 12/nr 3/2007.

Erixon Arreman, I. (2005). Att rubba föreställningar och bryta traditioner.

Forskningsutveckling, makt och förändring i svensk lärarutbildning. Umeå universitet, Institutionen för matematik, teknik och naturvetenskap.

Gulliksen M. S. \& Johansson M. (2008). Nuläge och framåtblickar - om undervisning och forskning inom det nordiska slöjdfältet. I: Techneserien - Forskning i slöjdpedagogik och slöjdvetenskap B:15/2008.

https://journals.hioa.no/index.php/techneA/article/view/3031.

Holmberg, A. (2009). Hantverksskicklighet och kreativitet. Kontinuitet och förändring $i$ en lokal textillärarutbildning 1955-2001. Uppsala universitet, Konstvetenskapliga institutionen.

Johansson, M. (2018). Doktorsavhandlingar inom det nordiska slöjdfältet. I Techne serien Forskning i Slöjdpedagogik och Slöjdvetenskap, 25(3), 109-123.

https://journals.hioa.no/index.php/techneA/article/view/3031.

Kokko, S., Almevik, G., Bentz Høgseth, H. C., och Seitamaa-Hakkarainen, P. (2020)

Mapping the methodologies of the craft sciences in Finland, Sweden and Norway. I:

Craft Research. Volume 11, Number 2. https://doi.org/10.1386/crre_00025_1 
Kyvik, S. (2009) The Dynamics of Change in Higher Education: Expansion and Contradiction in an Organisational Field. Higher Education Dynamics 27. Springer.

Kärnä-Behm, J. och Salo-Mattila, K. (eds.) (2002) Current Themes in Craft Research. I: Techneserien - Forskning i Slöjdpedagogik och slöjdvetenskap A:4/2002.

Lindfors, L (1992) På väg mot en slöjdpedagogisk teori. Paradigmutveckling och kunskapsbehållning. Sammanfattning av tre studier. Åbo Akademi/Österbottens högskola. Vasa.

Melbye, E. (2013) Det å forme i spennet mellom individ og kultur. Hovedfagsoppgaver i forming - Noen overveielser. I: Techneserien - Forskning i slöjdpedagogik och slöjdvetenskap B:17/2013.

Nielsen, L. M. Art, Design and Environmental Participation. Themes in Norwegian Studies 1995-2007. I: Lindström, L. (ed.) (2008) Nordic Visual Arts Education in Transition. A Research Review. Vetenskapsrådets Rapportserie 14:2008.

Nielsen, L.M. (red.) DesignDialog - designforskning i et demokratisk perspektiv. HiOrapport $2004 n r 22$. Högskolen i Oslo.

Nielsen, L. M. Research Programs for Reflective Practitioner. I: Lindström, L. (ed.) 1998 Nordic Visual Arts Research. A theoretical and Methodological Review. Stockholm Institute of Education Press.

Regeringens Proposition 1984/85:31 Lärarutbildning för grundskolan.

Samuelsen, A.M. Traditions and Methods in Visual Arts Research. I: Lindström, L. (ed.) 1998 Nordic Visual Arts Research. A theorethical and Methodological Review. Stockholm Institute of Education Press.

Svensk Författningssamling (SFS) 1977:283 Högskoleförordning.

Kajsa Borg, FD, docent, senior forskare Umeå universitet. Hennes forskningsintresse har på olika sätt berört slöjdområdet och slöjdämnets innehåll. Först riktat mot förändringar $\mathrm{i}$ grundskolans läroplaner och bedömningsfrågor $\mathrm{i}$ estetetiska ämnen i grundskolan. Med ökande erfarenhet och längre tidsperspektiv har hon också studerat och försökt förstå och analysera förändringar och förändringarnas effekter i svensk lärarutbildning i slöjd, där forskningsfrågorna har blivit alltmera betydelsefulla. Nordiskt och internationellt samarbete har varit en viktig inspirations- och kunskapskälla. 


\section{Bilaga med 113 avhandlingar}

Om ett universitet nämns en gång, anges det direkt efter avhandlingens titel. Om universitet nämns flera gånger, anges följande förkortningar:
AHO: Arkitektur- og designh øgskolen i
SU: Stockholms universitet Oslo.
TU: Turku university (Åbo universitet)
DPU: Danmarks pedagogiske universitet, Köpenhamn.
TUR: Turku university, Rauma.
UiO: Universitet I Oslo
GU: Göteborgs universitet
UiT: Universitet i Troms $\varnothing$
LiU: Linköpings universitet
UEF: University of Eastern Finland
HU: Helsingfors universitet
UiJ: University of Jyväskylä
NTNU: Norges tekniske-
UU: Uppsala universitet naturvitenskaplige universitet.
UmU: Umeå universitet
OU: Oulu University
ÅAV: Åbo Akademi, Vasa

Aakre, Bjørn Magne (2005) Formgivning og design i et didaktiskt perspektiv. NTNU. Ahlskog-Björkman, Eva (2007) Textil skapande som estetisk-etisk transformation. ÅAV. Alamäki, Ari (1999) How to educate students for a technological future: Technology education in early childhood and primary education. UT.

Alm, Anna (2012) Upplevelsens poetik. Slöjdseminariet på Nääs 1880-1940. Lunds Universitet.

Anttila, Pirko (1983) Work and work educability. A study on the structure of work education at school and various factors affecting it. HU.

Autio, Ossi (1997) Student's development in technical abilities in Finnish comprehensive school. Boys and girls in

an experiment of shared craft education. HU.

Berge, Britt-Marie (1992) Gå i lära till lärare, en grupp kvinnors och en grupp mäns inskolning $i$ slöjdläraryrket. UmU.

Borg, Kajsa (2001) Slöjdämnet, intryck - uttryck - avtryck. LiU.

Borgen, Jorun Spord (1997) Kunskabens stabilitet og flyktighet. Om forholdet mellom amatører og profesjonelle $i$ kunstfeltet. Universitet i Bergen.

Brænne, Karen (2009) Mellom ord og handling. Om verdsetjing i kunst og hantverksfaget. AHO.

Carlsen, Kari (2015) Forming i barnehagen i lys av Reggio Emilias atelierkultur. ÅAV.

Dagsland, Torunn P. (2013) Eleven som aktør i dialog med kunst. Ungdoms erfaring med kunstundervisningens innhold og metode i faget kunst og håndverk $i$ norsk grunnskole. ÅAV.

Dahrén, Lena (2010) Med kant av guld och silver. En studie av knypplade bårder och uddar av metall 1550-1640. UU.

Digranes, Ingvild (2009). Den kulturelle skulesekken. Narratives and myths of educational practice in DKS projects within the subject Art and Crafts. AHO.

Dunfjeld, Maja (2002). Tjaalehtjimmie: Form og innhold i sørsamisk ornamentikk. UiT. 
Ekström, Anna (2012) Instructional work in textile craft. Studies of interaction, embodiment and the making of objects. SU.

Elo, Janne (2015) Företagsamhet I skola och utbildning. Lärares tankar om förutsättningarna att nå målen i temaområdet Deltagande, demokrati och entreprenörskap. ÅAV.

Ericsson, Rose (2018) Retorik och praktik. En studie av Gestriklands hemslöjdsförening 1912-1930. UU.

Fredriksen, Biljana, (2012) Negotiating grasp: embodied experience with three-dimensional materials and the negotiating of meaning in early childhood education. AHO.

Fälling Andersen, Lisa (2020) Fra slфjd og håndarbejde till håndvark og design: En kulturanalytisk didaktisk og materiel undersøkelse af etablerings- og forandringsprocesser i fag og fagdidaktik. DPU, Aarhus universitet.

v Gegerfelt Kronberg, Sie (2012) Vilja, självtillit och ansvar. Kunskapens konstruktion $i$ skapande processer. ÅAV.

Glitsch, V.S. (2020) Fit step in ready-to-wear clothing. Towards a reduction of garment disposal in view of sustainability. University of Southeast Norway.

Groth, C. (2017) Making sense through hands: Design and craft practice analysed as embodied cognition. Aalto University, Helsingfors.

Gulliksen, Marte (2006) Constructing a formbild - An inquiry into the dynamical and hierarchical aspects of the hermeneutical filters controlling the formbild construction in design educational situations. AHO.

Guttorm, Gunvor (2003) Duodji Bálgát: en studie i duodji. Kunsthåndverk som visuell erfaring hos et urfolk. UiT.

Guttorm, Hanna (2014) Kompositioner och vändningar: nomadiska skrifter om forskningens början (och det genusbundna hantverket). HU.

Halvorsen, Else-Marie (1996) Kulturarv og kulturoverføring i grunnskolen med vikt på den estetiske dimen- sjonen. En begreps og erfaringssanalyse med ett didaktiskt perspektiv, UiO.

Hangh $\varnothing$, Sara (2007) Den konstituerende sofapude - materialisering set $i$ et kulturanalytiskt perspektiv. DPU.

Hansson Stenhammar, Mariel-Louise (2015) En avestetiserad skol- och lärandekultur. En studie om lärprocessers estetiska dimensioner. GU.

Hartman, Per (1993) Skola för ande och hand. En studie av folkhögskolans praktiskestetiska verksamheter. Högskolan för lärarutbildning, Stockholm.

Hartvik, Juha (2013) Det planlagda och det som visar sig. Klasslärarstuderandes syn på undervisning i teknisk slöjd. ÅAV.

Hasselskog, Peter (2010) Slöjdlärares förhållningssätt $i$ undervisningen. GU.

Hast, M (2011) Konstruktion från hantverksteknik: en analys- och tolkningsprocess av teknik som en del av ett generaliserat hantverksämne. Lapplands universitet.

Heinonen, A (2002) Självstyrd och utforskande studie inom teknikutbildning. Klasslärarutbildningsteknik Kursutvecklingsforskning. JU.

Helgadóttir, Gudrún (1997) Icelandic craft teachers' curriculum identity as reflected in life histories. University of British Colombia, Vancouver, Canada.

Hero, L-M (2019) Learning to develop innovations. Individual competence, multidisciplinary activity systems and student experiences. TU. 
Hilmola, Antti (2009) The search for the origins of planning and practicing sloyd education. Research into the factors guiding sloyd education contents planning and practicing in comprehensive school upper classes. UT.

Hofverberg, Hanna (2019) Crafting Sustainable Development. Studies of TEaching and Learning Craft in Environmental and Sustainablility Education. UU.

Holmberg, Annelie (2009) Hantverksskicklighet och kreativitet: Kontinuitet och förändring $i$ en lokal textillärar- utbildning 1955 - 2001. UU.

Homlong, Siri (2006) The languages of textiles. Description and judgement on textile pattern composition. UU.

Härkki, Tellervo (2018) Handling Knowledg: Three perspectives on embodied creation of knowledge in collaborative design. $\mathrm{HU}$.

Ihatsu, Anna-Marja (2002) Making sense of contemporary American craft. UiJ.

Illum, Bent (2004) Det manuelle håndvarksmassige og laring - processens dialog. DPU.

Jacobsson, Maja (1994) Käder som språk och handling, Om unga kvinnors användning av klädseln som kommunikation- och identitetsskapande medel. UmU.

Jeansson, Åsa (2017) Vad, hur och varför i slöjdämnet. Textillärares uppfattningar om innehåll och undervisning $i$ relation till kursplanen. UmU.

Jernström, Elisabeth (2000) Lärande under samma hatt. En lärandeteori genererad ur multimetodiska studier av mästare, gesäller och lärlingar. Luleå tekniska universitet.

Johansson, Marléne (2002) Slöjdpraktik i skolan - hand, tanke, kommunikation och andra medierande redskap. GU.

Johansson, Ulla (1987) Att skolas för hemmet. Trädgårdsskötsel, slöjd, huslig ekonomi och nykterhets-undervisning $i$ sen svenska folkskolan med exempel från Sköndals församling 1842-1919. UmU.

Järvinen, Esa-Matti (2002) Education about and through technology. In search for more appropriate pedagogical approaches to technology education. OU.

Kaasinen, J. (2014) Traditionell konstruktion som ett koncept och som en del av teknikutbildningen - lärarnas elevers strukturerade uppfattningar och förändringar under den traditionella byggkursen. UEF.

Kananoja, Tapani (1989) Work, Skill and Technology: About activity education and education for work in general education. UT.

Kangas, Kaiju (2014) The artifact project. Promoting designa learning in the elementary classroom. HU.

Kankare, Pasi, (1997) The context of technology education. TU.

Kantola, Jouko (1997) In the footsteps of Cygneus: From handicraft teaching to technological education. UiJ.

Karppinen, Seija (2005). Conceptual analysis of basic crafts education. HU.

Kaukinen, Leena (1995) Elongation behaviour of elastic stitch types in household sewing machines. Stretch-Stitches versus serger overlock stitches. HU

Kjosavik, Steinar (1998) Fra Ferdighetsfag till Forming. Utvickling fra tegning, sløjd og håndarbeit till forming sett ur et lareplanshistoriskt perspektiv. UiO.

Knutes, Helene, (2009) Gestaltandes pedagogik. Om att skapa konsthantverk. SU.

Koch, Marie (2012) Jag strikker, derfor er jag, Laring og identitet i uformelle laringsrom. AAV.

Kojonkoski-Rännäli, Seija (1998) The thoughts in our hands. An analysis of the meaning of the concept handicraft. TUR. 
Kokko, Sirpa (2006) The road to womanhood through gender-specific crafts. JU.

Kolehmainen, V. (1989) Utvärdering av det praktiska ämnesutvecklingsprogrammet som genomförs som utvecklingssamarbete mellan Zambia och Finland. TU.

Kouhia, Anna (2016) Unraveling the meanings of textile hobby crafts. UH.

Kragelund, Minna (1996) Opdragende håndarbejde. En undersøkelse af håndarbejdsfaget, dets metode og dets bevisthedsdannende virking i almueskolen ca. 1880-1910. Danmarks lærerhøjskole, København.

Kröger, Tarja (2003) The Diversity of www learning and teaching materials at the website "virtual craft space". UEF.

Laamanen, Tarja-Kaarina (2016) Generating and transforming representations in design ideation. HU.

Lahti, Henna (2008) Collaborative design in a virtual learning environment. Three design experiments in textile teacher education. HU.

Lappalainen, Eeva-Maija (2005)The culturally sensitive teaching:Uniting the learning of hand, language and cultura in teaching the immigrants and on the teacher's way growing towards the ethniccultural orientation and culturally sensitive teaching. OU.

Lepistö, Jaana (2004) Sloyd as an educational tool. A follow-up study on student' conceptions of sloyd as an educational tool before and after a basic level course sloyd in class teacher education. TU

Lindfors, Eila (2002) The technological properties of a textile product from the consumer perspective. UEF.

Lindfors, Linnea (1992) På väg mot en slöjdpedagogisk teori. Paradigmutveckling och kunskapsbehållning - sammanfattning av tre studier. ÅAV

Lindgren, Monica (2006) Att skapa ordning för det estetiska i skolan. GU.

Lindh, Matti (2006) On General Technological Education - the structure of technology learning and its application. UiO.

Liukov, V. (2018) Anchoring craft: The object as an intercultural and intertemporal unifying factor. HU.

Lutnæs, Eva (2011) Standpunktvurdering i grunnskolefaget Kunst og håndverk: Lareres forhandlingsrepertoar. AHO.

Luomalahti, M (2005) Teknisk inriktning av kvinnliga studenter i klasslärarutbildningen. Univ. i Tampere.

Luutonen, Marketta ((1997) Traditional artefact as a carrier of meaning. Research on the Finnish wollen jumper. HU.

Magga, Sigga-Marja (2018) Sami handicraft as a builder of unity: duodji norms and brands. OU.

Maapalo, Paulina, (2019) Øyeblickksbilder fra trearbeidspraksiser. Didaktiske og relasjonelle mulighetsrom for arbeid i materialet tre i kunst- og håndverksfaget. NTNU.

Malmberg, Eva (1995) Att upptäcka systemnätverk i edukativ slöjd. Analyser av elevens slöjdhandlingar i en kontext. En paradigmutvecklande ansats. ÅAV.

Malmberg, Kristina (2002) Knyppling - ett hantverk med spets. Om kvinnor och knyppling $i$ estlandssvensk tradition. GU.

Marjanen, Päivi (2012) Skolhantverk 1866-2003. Från mål som ökar hemmets välbefinnande till livsförmåga. TU.

Maus, Ingvill (2020) Enchancing design literacy for sustainability. Craft-based design for sustainability in lower secondary education in Norway. Oslo Metropolitan University. 
Metsärinne, Mika (2003) Sloyd vision teaching and learning. Case and action research on the 9 th classes. TU.

Mäkelä, Esko (2011) Slöjd som berättelse, om skolungdom och estetiska perspektiv. UmU.

Nielsen, Liv-Merete (2000) Drawing and spatial representations. Reflections on purposes for art education in the compulsory school. AHO.

Niiranen, S. (2016) Increasing girl's interest in technology education as a way to advance women in technology. UiJ.

Nygren-Landgärds, Christina (2000) Educational and teaching ideologies in sloyd teacher education. ÅAV.

Parikka, M. (1998) Teknisk kompetens. Utmaningar för att reformera teknikutbildningen $i$ grundskolorna. UiJ.

Peltonen, Juhani (1988) Grunderna för hantverks/slöjdutbildning. Skolarbete och dess undervisningsteori och teoretisk och empirisk forskning i grundskolan, Gymnasieutbildning och tekniskundervisning. TU.

Porko-Hudd, Mia (2005) Under ytan, vid ytan och ovanför ytan. Analys av tanken bakom tre läromedel i slöjd. ÅAV.

Randers-Pehrson, Anniken (2016) Tinglaging og laeringsrom i en kunst- og håndverksdidaktisk kontekst. UiO.

Rasinen, Aki (2000) Developing technology education. In search of curriculum elements for Finnish general education schools. UJ.

Reitan, Janne Beate (2007) Improvisation in tradition a study of contemporary vernacular clothing design practiced by Inupiaq women of Kaktovik, North Alaska. AHO.

Riis, Kristine (2016) Designkunskapens DNA. Udforskning af designkundskab gennem designprocessen Mit DNA. NTNU.

Rimstad, Åsta, (2015) Teikn- og meningsskaping i studentars arbeid med installasjonar. Norges arktiske universitet i Troms $\varnothing$.

Rogemoen, Marie (2012) Mellom tradisjon og spel. Didaktikk for tekstil folkekunst. ÅAV.

Räisanen, R. (2002) Anthraquinones from the Fungus Dermocybe sanquinea as Textile Dyes. HU.

Rönkkö, Marja-Leena (2011) Craft has many meanings. The meanings of craft perceived by the students in teacher education and how they are taken into account in craft teaching. TUR.

Seitama-Hakkarainen, Pirita (2000) The weaving design process as a dual-space search. HU.

Sigurdson, Erik (2014) Det sitter i väggarna. En studie av trä- och metallslöjdsalens materialitet, maskulinetet och förkroppsliganden. UmU.

Sjöberg, Barbro (2009) Med formgivning i fokus. En studie om holistisk slöjd $i$ lärarutbildningen. ÅAV.

Sjögren, Jan (1997) Teknik - genomskinlig eller svart låda? Att bruka, se förstå - fråga om kunskap. LiU.

Suojanen, Ulla (1991) The development of manual working processes and their teaching through action research. TU.

Syrjäläinen, Erja (2002) On the sourse of a craft teacher's pedagogical knowledge: Personal procedures and principles in craft teaching context. HU.

Thorsteinsson, Gisli (2012) Exploring the use of a virtual reality learning environment to support innovation education in Iceland. Loughborough University, United Kingdom. 
Tronshart, Bjørg (2016) Utstillingens retorikk: et bidrag till en retorisk didaktikk for kunst og håndverk. ÅAV.

Trotzig, Eva (1997) "sätta flickan i stånd att utföra sina husliga plikter." Fyra märkeskvinnor och flickors slöjdundervisning. LiU.

Turunen, Virpi (2015) Machine knitting with flax yarn. UEF.

Vartiainen, Leena (2010) Handicrafts and a sense of community. Networks, skills and shared experiences. UEF.

Vilhunen, Katja (2018) Knitting blog as a part of craft making - Experiences of combining blogging and handicrafts by knitting bloggers. UEF.

Viilo, Marjut, (2000) Teachers's orchestration in longitudinal collaborative inquiry process. HU.

Virta, Kalle (2005) Kindergarten, sloyd and classroom teacher trainees' self-directed learning, metacognitive regulation and web-based support. UT.

Väänänen, Niina (2020) Sustainable craft. Dismantled and reassembled. UEF.

Westerlund, Stina (2015) Lust och olust - elevers erfarenheter i textilslöjd. UmU.

Yliverronen, Virpi (2019) Förskoleslöjd: Tre fallstudier av förskolebarn och slöjd. HU. 
